\title{
Uma breve historiografia dos estudos brasileiros de religião nórdica medieval ${ }^{1}$
}

\section{A brief historiography of Brazilian studies on medieval Norse Religion}

Johnni Langer*

\begin{abstract}
Resumo
O presente artigo apresenta uma historiografia inicial dos estudos brasileiros referentes ao tema da religião nórdica antiga e cristã durante a Idade Média, abrangendo as perspectivas de mito, rito e magia. O período da pesquisa envolve os anos de 1959 até 2015 e diz respeito a livros, artigos, resenhas, entrevistas, eventos e pesquisas de pós graduação desenvolvidas por autores brasileiros. 0 objetivo da pesquisa é demonstrar o estado da área para as novas gerações, bem como fornecer aos pesquisadores avançados alguns parâmetros da inserção das investigações deste tema na academia brasileira. Como metodologia adotamos o referencial da História Cultural das Religiões e os debates críticos existentes entre os especialistas, em especial, Jens Peter Schjødt, Anders Andrén, Kristina Jennbert e Catharina Raudvere. Nossa principal conclusão demonstra que em pouco tempo, cerca de vinte anos, tais estudos alcançaram um relativo espaço (metodológico, analítico, bibliográfico e temático) no Brasil e certa repercussão internacional.
\end{abstract}

Palavras-chave: Religião Nórdica; Escandinávia Medieval; Mito e Rito.

\begin{abstract}
This paper presents a initial historiography of Brazilian studies on the topic of Old Norse and Christian religion during the Middle Ages, covering the prospects of myth, ritual and magic. The period of research involves the years 1959 to 2015 and refers to books, articles, reviews, interviews, events and posgraduate researchs developed by Brazilian authors. The objective of the research is to demonstrate the state of the area for future generations, as well as to provide to advanced researchers with some parameters of insertion of investigations on this subject in the Brazilian academy. The methodology we adopted is basead on the framework of Cultural History of Religions and existing critical debates among experts, in particular, Jens Peter Schjødt, Anders Andrén, Kristina Jennbert and Catharina Raudvere. Our main conclusion shows that in a short amount of time, about twenty years, these studies have reached a relative espace (methodological, analytical, bibliographical and thematic) in Brazil and some international repercussion.
\end{abstract}

Keyword: Norse Religion; Medieval Scandinavia; Myth and Ritual.

Artigo recebido em 14 nov. 2015 e aprovado em 14 set. 2016.

${ }^{1}$ Aqui nos remetemos ao conceito moderno dos estudos de religião, aplicado ao medievo, especialmente o que concebe a religião nórdica enquanto um sistema complexo de símbolos, rituais, narrativas mágicas e míticas, além das práticas que envolvem rituais (LANGER, 2016, p. 119-125).

* Doutor em História pela UFPR em 2001 e Pós-Doutor em História Medieval pela USP. Professor permanente do curso de graduação e pós graduação em Ciências das Religiões da UFPB. País de Origem: Brasil. E-mail: johnnilanger@yahoo.com.br

Horizonte, Belo Horizonte, v. 14, n. 43, p. 909-936, jul./set. 2016 - ISSN 2175-5841 


\section{Introdução}

A contínua ampliação dos estudos de religião no Brasil, especialmente na perspectiva histórica, vem possibilitando a inovação em campos temáticos dos mais variados. As experiências religiosas da Europa antiga e medieval, em particular, vem recebendo uma particular atenção dos pesquisadores brasileiros, mas nem sempre é possível aos novos investigadores acompanhar esta produção de um ponto de vista teórico ou metodológico. Nosso principal objetivo neste trabalho é conceder uma visão panorâmica e bibliográfica da produção envolvendo estudos de religiosidade nórdica no Brasil, ao mesmo tempo em que realizamos uma crítica ao estado da arte até este momento. ${ }^{2}$

Em primeiro lugar, o termo nórdico aqui é definido enquanto relacionado ao espaço geográfico escandinavo, incluindo a Suécia, Dinamarca, Noruega e Islândia. Abrangemos os períodos da Antiguidade Tardia e Alta idade Média, cobrindo o período politeísta até a conversão ao cristianismo e o fim do medievo.

Utilizamos o conceito de religião entendendo as crenças e práticas em torno do ritual ${ }^{3}$ e das instituições mantenedoras do espaço sagrado, mas também as experiências da religiosidade (como a magia, a cultura visual do sagrado e as narrativas míticas). Nosso principal referencial metodológico são os referenciais da História Cultural das Religiões, especialmente as que apontam a religião e a religiosidade como produtos culturais de uma determinada época e região, mas passíveis de serem interpretadas como representações (PETERS, 2015); de experiências produtoras de sentido e de práticas pelas comunidades históricas, além das visões de mundo (ALBUQUERQUE, 2007). No caso da religiosidade nórdica 4 antes da cristianização, adotamos as perspectivas de um fenômeno

\footnotetext{
${ }^{2}$ No presente trabalho não serão levados em consideração artigos, ensaios, livros e pesquisas de pós-graduação em estudos nórdicos medievais que não tenham relação direta com religiosidade (mito, rito ou magia). Ou seja, alguns estudos de História, Literatura, Arqueologia e outras áreas da Escandinavística Medieval produzidos no Brasil não serão avaliados no artigo.

${ }^{3}$ Entendemos ritual como um dos aspectos materiais da religião, onde as crenças, os símbolos, os mitos e as doutrinas são materializados em um determinado contexto espacial e histórico (LANGER, 2015a, p. 10-11).

${ }^{4}$ Entendemos religiosidade nórdica como um sistema complexo, repleto de tradições orais, míticas, mágicas e imaginárias, que vão muito além do ritual, fazendo parte de um sistema religioso não centralizado, não dogmático e não institucionalizado, vigente na Escandinávia da Era Viking (LANGER, 2016, p. 134).
}

Horizonte, Belo Horizonte, v. 14, n. 43, p. 909-936, jul./set. 2016 - ISSN 2175-5841 
cultural extremamente multidinâmico, com variações geográficas e temporais (ANDRÉN, 2006, p. 15).

Como metodologia, adotamos três referenciais básicos: o proposto por Elton Nunes (2011), ao analisar as pesquisas sobre religião na historiografia brasileira; em segundo, as intervenções analíticas do escandinavista Jens Peter Schjødt (2012) ao considerar as atuais metodologias de investigação sobre religião nórdica; e por último, um balanço crítico das pesquisas de historiadores brasileiros sobre o medievo (RUST \& BASTOS, 2009).

O objeto central deste artigo são as produções científicas (publicações e trabalhos em eventos acadêmicos) sobre o tema da religião nórdica medieval realizadas por brasileiros no contexto nacional. A produção é referente até o período de outubro de 2015. Além da produção impressa e disponível online, também utilizamos buscadores acadêmicos e ferramentas para determinar índices de impacto e referência (Google Scholar; Scielo; Banco de Teses da Capes). Na medida do possível e dentro dos limites de espaço deste artigo, realizaremos análises qualitativas deste material.

\section{As origens: 1959 a 2002}

Os estudos envolvendo a Escandinávia Medieval no Brasil não possuem uma tradição muito antiga. Durante o século XIX alguns acadêmicos estiveram envolvidos com a polêmica da suposta vinda de vikings ao nosso país antes de Cabral. Este debate esteve circunscrito ao âmbito de um pequeno círculo de intelectuais brasileiros e estrangeiros, vinculados ao Instituto Histórico e Geográfico Brasileiro e à administração do Império sediada no Rio de Janeiro.5 Houve poucas publicações neste período, apesar de certa correspondência entre os autores, inclusive com especialistas estrangeiros, mas que permanece inédita até nossos dias (HOLTEN; GUIMARÃES, 1997, p. 32-44). O interesse pelo tema era

\footnotetext{
${ }^{5}$ Por exemplo, Carl Rafn, Peter Claussen, Peter Lund, Rochus Schüch, Pierre Lerebous, Conde de La Hure, Manoel de Porto Alegre, João Barboza Rodrigues, entre outros.
}

Horizonte, Belo Horizonte, v. 14, n. 43, p. 909-936, jul./set. 2016 - ISSN 2175-5841 
puramente antiquário, mas em algumas situações a religiosidade conferia identidade aos nórdicos, como o debate sobre uma estátua do deus Thor em uma suposta cidade perdida da Bahia, ou os próprios vikings serem denominados de "filhos de Odin" por pesquisadores brasileiros do período (RODRIGUES, 1875, p. 99).

Foi somente em $1959^{6}$ que surgiu a primeira publicação acadêmica no Brasil envolvendo a religiosidade nórdica: Deuses e heróis na Edda Poética e na tetralogia de Wagner, de Sonia Heinrich de Mattos. Tratava-se de sua tese de livre-docência apresentada para a cátedra de língua e literatura alemã na Universidade de São Paulo. A origem da pesquisa remonta à permanência desta professora na Universidade de Heidelberg (Alemanha) em 1954, onde tomou contato com pesquisas envolvendo a obra de Richard Wagner. E é dentro desta perspectiva que o seu trabalho se insere: analisar as influências mitológicas na ópera alemã do século XIX. A pesquisa realiza uma rápida síntese de conteúdo sobre os principais poemas éddicos (contidos no Codex Regius), seguida da análise de sua influência na obra $\mathbf{O}$ anel dos Nibelungos de Wagner. Devido a sua formação e contatos europeus, a professora Sonia Mattos foi muito influenciada pelas ideias culturais advindas do Romantismo alemão: a antiga língua e os mitos dos diversos povos de origem germânica possuíam uma identidade em comum, que poderia ser resgatada como expressões arcaicas das nações modernas. Isso também é nítido em suas afirmações de que a Islândia (o local de origem do Codex Regius) seria o "abrigo seguro contra as influências do novo credo" (MATTOS, 1959, p. 11). Outro indício desta influência alemã é a não utilização dos termos escandinavos e nórdicos para as fontes medievais em geral, preferindo o conceito de mitologia germânica, empregado ao longo do texto. A principal influência teórica acerca dos mitos e citada na bibliografia são os livros Deutsche Mythologie, de Jacob Grimm (publicado originalmente em 1835) e Mythologie der Germanen, de Elard Hugh Meyer (original de 1891). Ambos possuíam uma visão naturalista dos

\footnotetext{
${ }^{6}$ Anteriormente ocorreu a tese “O comércio varegue e o Grão-Principado de Kiev", de Eurípedes Simões de Paula (USP, 1942), mas que não tratava de temática religiosa.
}

Horizonte, Belo Horizonte, v. 14, n. 43, p. 909-936, jul./set. 2016 - ISSN 2175-5841 
antigos mitos, transformados em monumentos da história humana e base para o nacionalismo alemão (especialmente o Volksgeist, o espírito da nação), do qual Mattos foi diretamente influenciada.

Figura 1

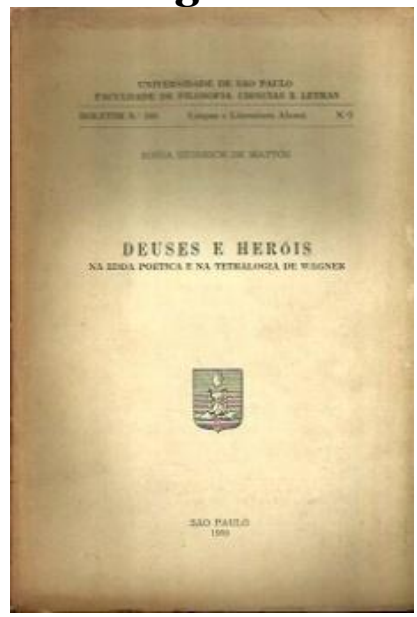

Figura 3

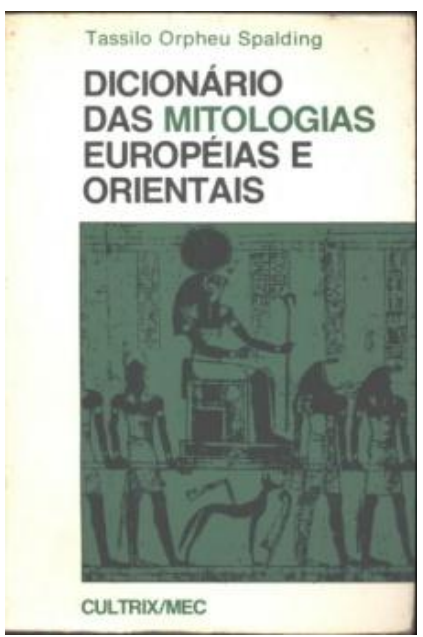

Figura 2

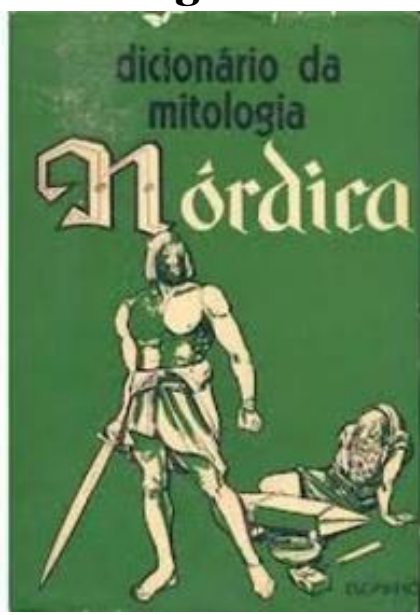

Figura 4

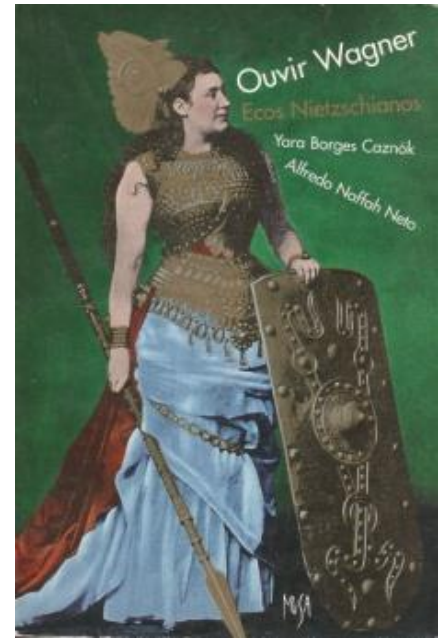

Fontes:

Figura 1: Deuses e heróis na Edda Poética e na tetralogia de Wagner, de Sonia Henrich de Mattos, 1959;

Figura 2: Dicionário de Mitologia Nórdica, de Esopinho, s.d.;

Figura 3: Dicionário das Mitologias Européias e Orientais, de Tarsilo Spalding, 1973; Figura 4: Ouvir Wagner, ecos nietzschianos, de Yara Caznók e Alfredo Neto, 2000.7

\footnotetext{
${ }^{7}$ As imagens de capa destas edições são influenciadas pelo pouco conhecimento técnico e editorial do período, a respeito da temática. O segundo livro reproduz claramente um referencial da Antiguidade clássica, sem relação com o mundo medieval nórdico. A quarta capa reproduz uma fotografia de ópera wagneriana, condizente com o seu conteúdo.
}

Horizonte, Belo Horizonte, v. 14, n. 43, p. 909-936, jul./set. 2016 - ISSN 2175-5841 
A obra de Sonia Mattos não teve maiores repercussões na academia e não gerou influências posteriores, como veremos. ${ }^{8}$ Durante os anos 1960 à década de 1990, praticamente não houve pesquisas acadêmicas sobre a religiosidade nórdica. Apenas como menção, citamos duas obras de popularização publicadas nesta época: Dicionário de mitologia nórdica, de Esopinho (s.d.) e Dicionário de Mitologia Germânica (incluído em Dicionário das mitologias européias, 1973), de Tarsilo Orpheu Spalding. Tratava-se de duas obras de caráter enciclopédico, com teor descritivo e pouco analítico e cujos escritores e tradutores retiraram as informações de bibliografias secundárias, sem ter acesso direto às fontes primárias das mitologias antiga e medieval. A sua importância deve-se muito mais ao fato de tornarem o tema mais acessível ao grande público, mas como a obra de Sonia Mattos, não geraram maiores influências na academia brasileira.

Por sua vez, a década de 1990 é um período de transição e onde temos as raízes da moderna Escandinavística brasileira. Isso se explica por três motivos básicos. Em primeiro lugar, foi a partir do final desta década que se multiplicaram no Brasil a quantidade de especialistas em estudos medievais, laboratórios e centros de pesquisas e os títulos traduzidos sobre este período histórico, redimensionando uma nova legitimidade acadêmica nas universidades brasileiras (RUST \& BASTOS, 2009, p. 7).

Em segundo, temos a tradução no Brasil, em larga escala de vários manuais sobre história e cultura dos vikings. 9 Por último, algumas fontes e estudos sobre mitologia nórdica foram também traduzidos neste mesmo contexto, popularizando a temática. O mais importante destes materiais sem sombra de dúvida é a Edda em Prosa, traduzida por Marcelo Magalhães Lima para a editora Numen em 1993.

\footnotetext{
${ }^{8}$ Mesmo assim, recebeu seis citações no Google Scholar (acesso em 20 de outubro de 2015).

${ }^{9}$ Os Vikings: História de uma fascinante civilização, de Johannes Brondsted (s.d.); Os vikings, de Michael Gibson (1990); Os vikings: reis dos mares, de Yves Cohat (1991); Vikings, de Fiona Macdonald (1996); Os viquingues: origens da cultura escandinava, de James Graham-Campbell (1997); As invasões normandas: uma catástrofe? De Albert D’Haenens (1997).
}

Horizonte, Belo Horizonte, v. 14, n. 43, p. 909-936, jul./set. 2016 - ISSN 2175-5841 
Apesar de suas inúmeras desqualificações ${ }^{10}$, ela foi importante para a expansão da área neste período. Outras fontes germano-escandinavas foram impressas nesta época, também traduções diretamente do inglês moderno, mas com maior qualidade editorial, como Beowulf (traduzida por Ary Gonzalez Galvão em 1992), ou adaptações traduzidas do alemão: Sagas de heróis e cavaleiros: mitos germânicos (traduzido por Gisela Eckschmidt em 1996).

Como terceiro, temos as traduções estrangeiras, certamente os livros com maior qualidade textual deste momento. O manual introdutório Mitos nórdicos, do epigrafista britânico Raymond Ian Page (1999), realizou uma grande contribuição ao fornecer excelentes discussões metodológicas e conceituais aos estudos dos mitos nórdicos, também apresentando 23 fotografias de imagens nórdicas medievais envolvendo temas míticos e religiosos e não meras reproduções da arte moderna, e de maneira ainda mais profícua, a tradução do clássico Do mito ao romance, de Georges Dumézil (1992), apresentou a primeira análise profunda sobre a religiosidade nórdica medieval ao público brasileiro.

Dois livros produzidos por brasileiros no final da década de 1990 destacamse pelo pioneirismo temático. ${ }^{11} \mathrm{O}$ primeiro, Ouvir Wagner, ecos nietzschianos (2000), de Yara Caznók e Alfredo Neto, segue a tendência inaugurada por Sonia Mattos. Ambos com formação em Psicologia, mas utilizando-se dos referenciais teóricos da Estética e da Filosofia, concentram suas análises na relação da obra de Wagner com a arte e o pensamento oitocentista. Com poucas indicações de teoria do mito (citando apenas Junito de Souza Brandão) e praticamente nenhuma referência a estudos específicos de mitologia germânica ou nórdica, o livro contribuiu muito pouco para o desenvolvimento da área, um caso bem diferente de

\footnotetext{
${ }^{10}$ A tradução foi realizada do inglês para o português e não do original, em nórdico antigo; não utilizou critérios acadêmicos de tradução; o autor suprimiu diversas passagens da narrativa em prosa e dos trechos poéticos, desqualificando o livro como material de referência para os estudos rigorosos da área.

${ }^{11}$ Apesar de não tratarem de temas religiosos, outras duas publicações na década de 1990 também foram pioneiras na Escandinavística brasileira e ajudaram a implantar os estudos sobre os vikings em nosso país: a brilhante análise do conto islandês de Helgi Thorisson, realizada por Ciro Flamarion Cardoso (capítulo do livro Narrativa, sentido, História, de 1997, p. 67-82); o artigo Desfazendo as ilusões: o dr. Lund e a suposta presença escandinava na terra de Santa Cruz, Locus, 1997, da dinamarquesa Birgitte Holten e da historiadora brasileira Lucia Guimarães.
}

Horizonte, Belo Horizonte, v. 14, n. 43, p. 909-936, jul./set. 2016 - ISSN 2175-5841 
Manifestações do sagrado na épica medieval (2000), de Sérgio Almeida. A obra apresenta a análise de três fontes literárias medievais com conexão com o sagrado (A canção de Rolando; O cantar de Mio Cid; A canção dos Nibelungos). A que mais interessa aos estudos nórdicos é a última, uma das fontes diretas de Wagner para sua tetralogia. Sérgio Almeida possuía formação em Letras e inovou ao apresentar alguns autores consagrados ao estudo dos mitos nórdicos (mas ainda pouco conhecidos do Brasil de então), como Régis Boyer, Hilda Davidson, Renaud Kranz e Else Roesdahl. Também inovou ao mudar o objeto do estudo, afastando-se da arte moderna e dirigindo seu foco para o Medievo. O problema da obra são suas particulares aplicações da Fenomenologia (ao adotar autores como Eliade, Otto e Jung), mescladas com fantasias e comparações anacrônicas. Como exemplo, comparando as aventuras da personagem Kriemhild com festas cristãs, tarô, numerologia e I-ching (ALMEIDA, 2000, p. 147-151), tendo como base a ideia de que o sagrado é o mesmo e imanente a todos os seres humanos e a todas as épocas, sem distinções de sociedade, cultura ou localidade, o autor perde o rigor acadêmico e aventura-se em interpretações de caráter fantástico.

\section{0 período inicial: 2003 a 2011}

A partir de 2003 o Brasil conheceu suas primeiras publicações envolvendo diretamente temas e estudos de fontes medievais sobre religiosidade nórdica. Praticamente, a grande maioria da produção temática neste intervalo de tempo concentrou-se na revista semestral Brathair de Estudos Celtas e Germânicos, num total de 36 trabalhos $^{12}$, divididos entre os pesquisadores: Artur César Isaia e André Yamamoto (1 artigo), João Bittencourt de Oliveira (3 artigos), Patricia Pires Boulhosa (2 artigos), Ciro Flamarion Cardoso (2 artigos, 1 entrevista), Pablo Gomes de Miranda (1 artigo), Álvaro Bragança Júnior e Tiago Quintana (1 artigo), Solange

\footnotetext{
${ }^{12}$ Esse levantamento quantitativo da revista Brathair não incluiu material geral (traduções, resenhas, artigos) sobre Escandinávia Medieval (como História, cultura, literatura), mas somente e exclusivamente trabalhos envolvendo religiosidade nórdica (rito, mito, magia).
}

Horizonte, Belo Horizonte, v. 14, n. 43, p. 909-936, jul./set. 2016 - ISSN 2175-5841 
Ramos de Andrade e Flávio Palamin (1 artigo), Luiz Claudio Moniz Telles (1 artigo), Renan Marques Birro e Ricardo da Costa (1 artigo), Johnni Langer (10 artigos, 8 resenhas e 4 organizações de entrevistas).

Estes trabalhos foram publicados nas sessões livres ou nos dossiês temáticos do periódico, muitos relacionados objetivamente com a área: Mitologia e religião celta e germânica (v. 4, n. 1, 2004); Mitologia germânica e celta (v. 6, n. 2, 2006); Morte, funeral e vida após a morte (v. 8, n. 1, 2008); Sagas islandesas (v. 9, n. 1, 2009); Paganismo e cristianismo entre os celtas e germanos (v. 10, n. 1, 2010); Estudos Vikings (v. 11, n. 1, 2011).

Entre todos estes trabalhos publicados na revista Brathair de 2003 a 2011³, consideramos para análise os quatro artigos mais paradigmáticos de um ponto de vista teórico e metodológico e aqueles com maior repercussão acadêmica $^{14}$, dois envolvendo mitologia nórdica e dois tratando de religiosidade nas sagas islandesas. O primeiro é Breves observações sobre a Edda em Prosa ${ }^{15}$ (2004), de Patricia Pires Boulhosa. Com formação em História e Direito, Boulhosa concede uma perspectiva totalmente inovadora ao panorama investigativo brasileiro, ao apresentar uma discussão codicológica e documental para uma das mais importantes fontes da mitologia nórdica, a Edda de Snorri Sturluson. Influenciada pelas ideias de Anthony Faulkes e John Mckinell sobre mito e literatura, Boulhosa discute as variações entre os manuscritos medievais e como esta perspectiva pode esclarecer a pluralidade das tradições míticas e religiosas da Escandinávia Medieval e, mais ainda, questionar a ideia de uma religião pré-cristã imutável ou fixa aos moldes do cristianismo (BOULHOSA, 2004, p. 13-18).

\footnotetext{
${ }^{13}$ No período de 2012 a 2015 (edições v. 12, n. 1 a v. 15, n.2) a revista Brathair não publicou nenhum tipo de estudo envolvendo religiosidade nórdica escrito por pesquisador brasileiro, motivando este período a ficar de fora da presente historiografia. $\mathrm{O}$ artigo escandinavista publicado na revista Brathair que obteve o maior índice de repercussão foi "As Estelas de Gotland e as Fontes Iconográficas da Mitologia Viking: os Sistemas de Reinterpretações Oral-Imagéticos" (Volume 6, n. 1, 2006) que atingiu vinte citações no Google Scholar (acesso em 20 de outubro de 2015).

${ }^{14}$ Não levamos em considerações os artigos de autores estrangeiros na Brathair, traduzidos ou na língua original. Consideramos como repercussão acadêmica a quantidade de citações detectadas no Google Scholar e em citações estrangeiras de periódicos e pesquisas.

${ }^{15}$ Artigo com oito citações no Google Scholar (acesso em 20 de outubro de 2015).
} 
Outro estudo foi Aspectos da cosmogonia e da cosmografia escandinavas ${ }^{16}$ (2006), do falecido historiador Ciro Flamarion Cardoso (UFF). Conhecido pelas suas publicações em Teoria da História e Egiptologia, Cardoso também realizou diversas investigações no campo da religiosidade nórdica medieval ${ }^{17}$. Aqui ele realiza várias discussões conceituais e teóricas, entre as quais, os limites e as diferenças entre a utilização da Edda em Prosa em relação à Edda Poética e as críticas aos conceitos de religião utilizados pelos Escandinavistas em geral. Como estudo de caso, Cardoso concentrou-se nos aspectos cosmogônicos do poema Völuspá (o primeiro do Codex Regius), utilizando como ferramenta analítica a crítica literária do formalismo russo (CARDOSO, 2006, p. 32-48). Trata-se de um vigoroso exemplo de estudo de caso, mas sem deixar as discussões teóricas e bibliográficas em segundo plano, tornando-se um artigo paradigmático neste período.

Em terceiro e quarto, temos dois estudos publicados no dossiê Sagas islandesas de 2009, que demonstram o locus privilegiado destas fontes literárias para o entendimento das práticas religiosas nórdicas durante o Medievo. O professor de literatura inglesa João Bitencourtt de Oliveira (UERJ), contribuiu com $\mathrm{o}$ artigo Aventura e magia nas sagas islandesas ${ }^{18}$, em que procura desvendar o papel da magia nestas narrativas literárias, seja como simples tema de obstáculo no transcurso das aventuras heroicas das sagas lendárias, ou como assunto cotidiano na vivência social e doméstica das sagas de família. Dentre os referenciais bibliográficos destacamos a menção a Régis Boyer, Jesse Byock e Carol Clover. Oliveira adota o referencial clássico de feitiçaria como sinônimo de magia para a desenvolvida pela historiografia até os anos 1960, e mais particularmente, de magia nórdica como semelhante ou igual ao xamanismo (especialmente o adotado por Hilda Davidson) (OLIVEIRA, 2010). Apesar destas limitações conceituais, o artigo

\footnotetext{
${ }^{16}$ Artigo com seis citações no Google Scholar (acesso em 20 de outubro de 2015).

${ }^{17}$ Citamos aqui também outras publicações deste autor: A interpenetração da cosmogonia religiosa com a história entre os escandinavos, Nearco 9, 2012; O paganismo anglo-saxão: uma síntese crítica, Brathair 4(1), 2004; Beowulf e as estruturas da Escandinávia Pré-Viking, Notícias Asgardianas 44, 2004; O paganismo na Europa Setentrional, Brathair 4(2), 2004.

${ }^{18}$ Artigo com nove citações no Google Scholar (acesso em 20 de outubro de 2015).
}

Horizonte, Belo Horizonte, v. 14, n. 43, p. 909-936, jul./set. 2016 - ISSN 2175-5841 
apresenta-se como um excelente estudo de fontes primária, tornando-se um referencial quase obrigatório nas pesquisas posteriores sobre a área.

Outro artigo do dossiê foi Galdr e feitiçaria nas sagas islandesas ${ }^{19}$, escrito pelo historiador Johnni Langer (UFPB). Nele, o autor debruça-se a analisar o conteúdo pré-cristão do poema Buslubæn, inserido na Saga de Bosi, um manuscrito tardo-medieval. Além do conteúdo temático em si, analisado dentro da perspectiva dos estudos de magia e feitiçaria europeia (especialmente influenciado pela historiografia francesa), o pesquisador discute o papel da relação entre oralidade e historicidade nas fontes literárias, tendo como principais influências escandinavistas como Thomas DuBois, Lorenzo Gallo e Stephen Mitchell. O principal ponto defendido pelo pesquisador é o de uma continuidade híbrida da magia pré-cristã após a conversão da Escandinávia, especialmente na prática do galdr (LANGER, 2010, p. 66-90). Este artigo teve certa repercussão internacional, sendo referenciado no periódico finlandês RMN Newsletter (LESLIE, 2012, p. 160) e posteriormente, citado em uma tese de doutorado norueguesa: The Prose Contexts of Eddic Poetry: Primarily in the Fornaldarsogur (LESLIE, 2013, p. $452-456) .^{20}$

Um importante sintoma do avanço das investigações temáticas na academia nacional deste momento foram alguns eventos que discutiram diretamente a área. Apesar de alguns estudos surgirem esporadicamente em apresentações de trabalhos individuais, o primeiro evento tratando diretamente do assunto foi o $I$ Colóquio de Estudos Celtas e Germânicos: Religiosidade e interpretatio, ocorrido na UFF em 2007. Com a participação de alunos e professores envolvidos com os estudos nórdicos, este encontro também foi a primeira experiência brasileira que refletiu novas concepções sobre as ideologias das fontes, em especial a

\footnotetext{
${ }^{19}$ Artigo com seis citações no Google Scholar (acesso em 20 de outubro de 2015).

${ }^{20}$ Outro artigo em língua portuguesa escrito por Johnni Langer também foi citado na Europa, a exemplo de Morte, sacrifício humano e renascimento (Mirabilia 3, 2003), que foi citado no artigo Der Tod des Todes (Zeitschrift für Spiritualität und Transzendentale Psychologie 2011, 1 (2)), de autoria de Bernhard Wegener. A revista Brathair também teve outro artigo envolvendo religiosidade nórdica sendo citado em publicação internacional. O livro Witchcraft and Magic in the Nordic Middle Ages (2011) de Stephen Mitchell referenciou o artigo The archaeology of seidr, de Neil Price (Brathair 4(2), 2004). Isso demonstra o alcance destas publicações na academia, ao mesmo tempo em que servem como propulsoras das novas gerações de pesquisadores.
}

Horizonte, Belo Horizonte, v. 14, n. 43, p. 909-936, jul./set. 2016 - ISSN 2175-5841 
interpretatio romana e a interpretatio norrœena, demonstrando uma afinidade com as discussões mais recentes da comunidade internacional. Um destaque particular foi a palestra $A$ interpenetração da cosmogonia com a história entre os escandinavos, de Ciro Cardoso, posteriormente publicada na revista Nearco 9 (2012). Neste trabalho, o historiador discute como o imaginário religioso estava inserido profundamente no cotidiano social e político da Escandinávia pré-cristã, ao mesmo tempo em que reflete sobre algumas fontes cristãs e seus referenciais sobre o passado pagão (como nos relatos de Adão de Bremen e Saxo Grammaticus).

Figura 5

\section{Colóquio de Estudos Celtas e Germânicos: Religiosidade e interpretatio}

21 e 22 DE JUNH० DE 2007

UNIVERSIDADE FEDERAL FLUMINENSE, NITERÓI, RJ
Figura 6

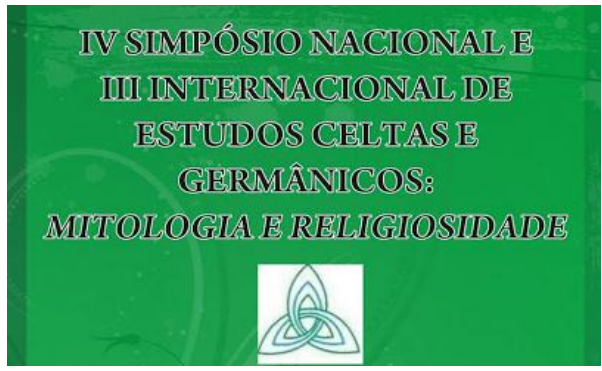

Fontes:

Figura 5: Cartaz do I Colóquio de Estudos Celtas e Germânicos: Religiosidade e interpretatio, UFF, 2007;

Figura 6: Cartaz do III Simpósio Internacional de Estudos Celtas e Germânicos: Mitologia e Religiosidade, UFMA, 2010. ${ }^{21}$

Também merece menção a realização em 2010 do III Simpósio Internacional de Estudos Celtas e Germânicos²2: Mitologia e Religiosidade, ocorrido na UFMA. Alargando amplamente tanto as discussões teóricas quanto temáticas envolvendo mito e rito nórdicos, este simpósio também originou o livro A religiosidade dos celtas e germanos, publicado na mesma época do evento, com organização de Luciana de Campos. O destaque é o capítulo Discussões etimológicas e religiosas sobre os berserkir e os ulfheðnar²3, de Pablo Gomes de

\footnotetext{
${ }^{21}$ A imagem do cartaz do IV SINECG contém alusão a um triskelion, símbolo celta e germânico antigo, triplicado. Esse símbolo da identidade pré-cristã foi abandonado posteriormente, nas outras edições deste evento.

${ }^{22}$ Não avaliamos aqui as outras edições do SINECG, por conterem poucas inclusões de temas religiosos nórdicos. O grupo Brathair, aos poucos, afastou-se da Escandinavística, como podemos perceber na última edição de seu evento, VI SINECG, na UEMA, onde nenhuma atividade de conferência, minicurso ou mesa redonda tem qualquer relação com os estudos nórdicos.

${ }^{23}$ Capítulo com duas citações no Google Scholar (acesso em 20 de outubro de 2015).
} 
Miranda, seja pela originalidade da abordagem, buscando compreender os significados religiosos pela sua etimologia, seja buscando novos horizontes e problemáticas para o estudo dos cultos odínicos e a figura dos nórdicos relacionados ao frenesi guerreiro (MIRANDA, 2010, p. 165-175).

Por fim, ainda destacamos durante o período até o ano de 2011 a publicação de dois importantes livros para a divulgação de pesquisas sobre a fé nórdica em suas múltiplas variações medievais. Em 2008 a historiadora Maria Regina Candido (UERJ) organizou a obra Mitologia germano-escandinava: do chaos ao apocalipse, reunindo de graduandos a doutores para investigar alguns estudos de casos, revisões bibliográficas e artigos de sistematização da área. Apesar de certo espaço conquistado pelo livro, o mesmo possui algumas limitações e problemas. Em seu editorial, a organizadora menciona que "Atualmente, percebe-se um acentuado interesse sobre a Antiguidade da cultura germânica, escandinava e viking, acompanhado de descobertas arqueológicas que permitem novas abordagens da mitologia e da religião" (CANDIDO, 2008, p. 5), o que aponta certa confusão neste período acerca dos termos escandinavo e viking. ${ }^{24}$ Além disso, a maioria dos estudos do livro não incluiu abordagens arqueológicas sobre o tema da religiosidade. Pelo menos dois capítulos são deficitários quanto a abordagens teóricas, como Ragnarok: o crepúsculo dos deuses, do historiador Alan Dias, com um texto extremamente descritivo, sem uma abordagem profunda sobre a mitologia e elencando os deuses em forma alfabética, utilizando referenciais puramente enciclopédicos e popularizadores (CANDIDO, 2008, p. 61-67). Outro trabalho, Thor: o deus do trovão, do filósofo Luiz Moniz, perpetua o velho referencial duméziliano da tripartição social, ao mesmo tempo em que mescla suas análises com a fenomenologia de Mircea Eliade (CANDIDO, 2008, p. 36-45). Anteriormente, a academia brasileira já havia realizado uma profunda crítica da aplicação da teoria da tripartição nos mitos nórdicos, como no artigo $A$ mitologia

\footnotetext{
${ }^{24} \mathrm{Em}$ um sentido histórico e pelos referenciais fornecidos pelas fontes, podemos afirmar que todo viking era escandinavo, mas nem todo escandinavo era viking. $O$ termo viking está condicionado a uma série de práticas marítimas efetuadas por alguns nórdicos da sociedade na Era Viking e não é sinônimo direto de nórdico, escandinavo ou normando. Sobre o assunto, ver: LANGER, 2009, p. 133147; AYOUB, 2012, p. 1-14.
}

Horizonte, Belo Horizonte, v. 14, n. 43, p. 909-936, jul./set. 2016 - ISSN 2175-5841 
escandinava de Georges Dumezil, de Patrícia Boulhosa (Brathair 6, 2006), mas não citado por Moniz.

Figura 7

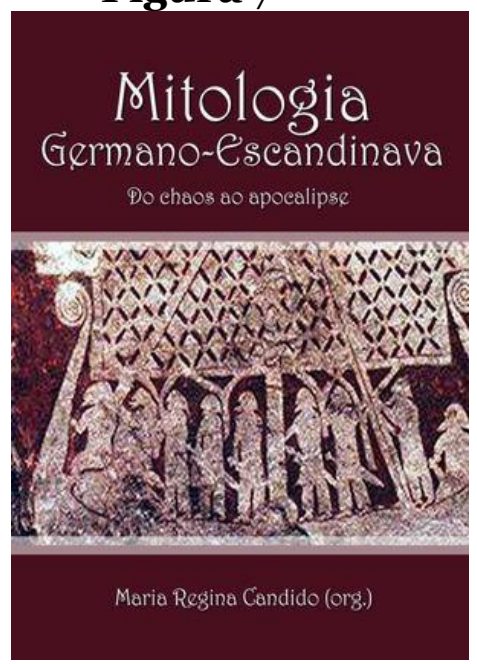

Figura 9

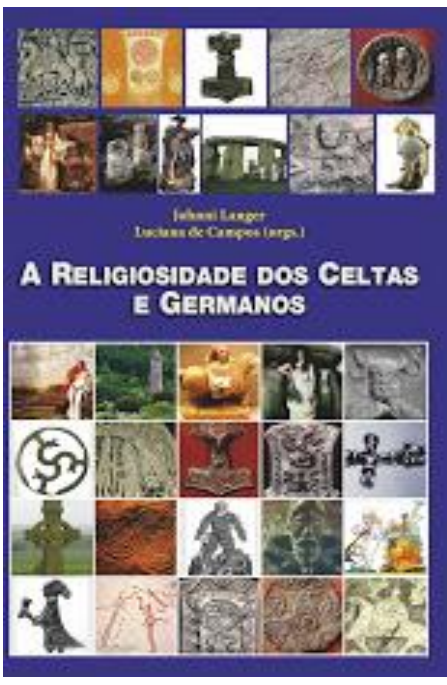

Figura 8

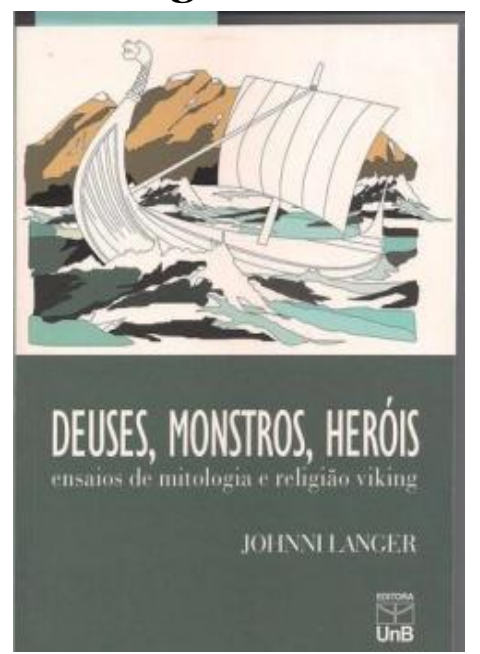

Figura 10

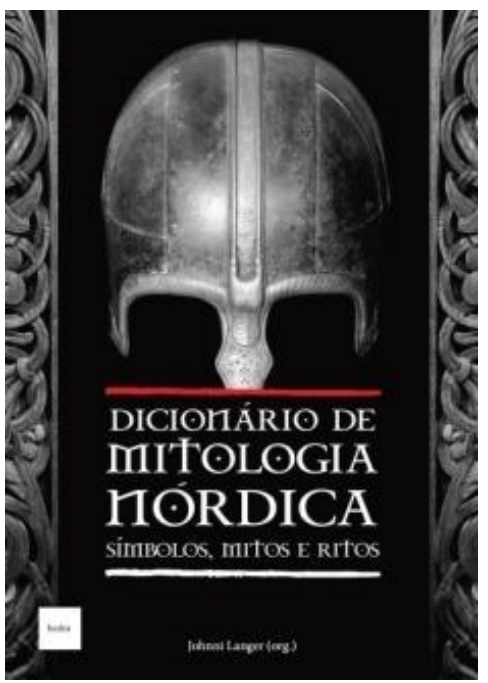

Fontes:

Figura 7: Mitologia germano-escandinava, organizado por Regina Cândido, 2008;

Figura 8: Deuses, monstros, heróis, de Johnni Langer, 2009;

Figura 9: A religiosidade dos celtas e germanos, organizado por Luciana de Campos, 2010;

Figura 10: Dicionário de Mitologia Nórdica, publicado pela editora Hedra, 2015. 25

\footnotetext{
${ }^{25}$ As capas dos livros 7, 8 e 10 fazem alusão aos aspectos bélicos e náuticos dos nórdicos - extremamente importantes para o imaginário popular e definidores de um público consumidor desta temática. A capa 9, por sua vez, apresenta diversos símbolos e elementos materiais da religiosidade nórdica antiga e medieval, um avanço no sentido editorial e que condiz mais diretamente com o seu conteúdo.
}

Horizonte, Belo Horizonte, v. 14, n. 43, p. 909-936, jul./set. 2016 - ISSN 2175-5841 
Em 2009 o historiador Johnni Langer publicou o livro Deuses, monstros, heróis ${ }^{26}$ pela editora da Universidade de Brasília, uma coletânea de seus artigos produzidos entre 2000 a 2005 e originalmente inseridos nos periódicos Viking Heritage, European Journal of Archaeology, Temas Medievales, Revista de História da USP, Varia Historia, Signum, Mirabilia e Brathair. Percebe-se nitidamente uma influência da historiografia francesa nesta obra, em especial da Nova História de Jacques Le Goff e seus referenciais de análise do imaginário medieval, bem como novas considerações sobre o uso de fontes alternativas para o estudo do passado. Ao mesmo tempo em que investiga as ressignificações da religiosidade e da cultura nórdica no mundo contemporâneo, em especial pelas artes em geral, em outros momentos o autor preocupa-se em resgatar os mitos, as práticas mágicas e os rituais da Escandinávia da Era Viking, especialmente por meio de fontes visuais (LANGER, 2009, p.1-285). Aqui se percebe uma influência de autores preocupados com a cultura material do mito no Medievo, como Régis Boyer, Neil Price e Preben Sørensen. Essa certamente é a maior contribuição desta obra, trazer ao público novos caminhos na interpretação da mitologia medieval nórdica, em especial pelo viés da cultura visual - mas que ao mesmo tempo se torna sua grande deficiência, pois o livro, de forma diferente dos artigos originais, não apresenta as fontes iconográficas, dificultando aos leitores seguir profundamente as interpretações do autor.

Neste mesmo ano de 2009 ocorreram outras duas publicações muito especiais, de um ponto de vista da divulgação e do alcance acadêmico que promoveram. O historiador Pedro Paulo Funari lançou o livro As religiões que o mundo esqueceu, uma coletânea reunindo as religiosidades de vários povos da Antiguidade e do Medievo. Declarando que a religião é o grande diferencial da cultura humana em relação a sua herança biológica, Funari também alega que este livro "dedica-se a algumas das mais interessantes e inspiradoras experiências religiosas da humanidade que deixaram de existir" (FUNARI, 2009, p. 8). Se antes

\footnotetext{
${ }^{26}$ Livro com vinte e cinco citações no Google Scholar (acesso em 20 de outubro de 2015).
} 
a fé nórdica era um assunto totalmente marginal na academia brasileira, agora ela recebe um espaço especial, ao lado dos egípcios, gregos, romanos, entre outros. ${ }^{27}$ Ela é pensada como uma experiência não-revelada e histórica, bem aos moldes dos anteriores trabalhos de Ciro Cardoso na revista Brathair. Indo muito além da mera descrição de seu panteão de deuses e criaturas sobrenaturais, o livro recupera também a sua filosofia e concepções de mundo, vida após a morte, rituais e práticas, sacerdócio, templos e magia. Também temos algumas menções ao neopaganismo nórdico (que já vem ocupando certa importância social até mesmo no Brasil) e uma crítica das fontes primárias (FUNARI, 2009, p. 130-143). Sem dúvida, a religiosidade escandinava já deixava de ser um assunto menor nos debates científicos.

Por fim, temos a tradução do nórdico antigo ao português de uma das mais importantes fontes da mitologia nórdica, Saga dos Volsungos, realizada em 2009 por Théo de Borba Moosburger. Com uma introdução bem estruturada, além de notas, resumo e índice, a obra definitivamente levou o tema da mitologia nórdica a um alcance público jamais antes visto em nosso país, sendo citada em pesquisas, artigos, resenhas e apresentações em eventos e inclusive, sendo tema central de dissertação de mestrado em Ciências das Religiões (AMORIM, 2013).

\section{0 período recente: 2012 a 2015}

Um momento particularmente importante nos estudos nórdicos brasileiros foi a criação em 2010 do Núcleo de Estudos Vikings e Escandinavos (NEVE), um grupo acadêmico interinstitucional que abarca pesquisadores de diferentes estados e de áreas diferentes, mas essencialmente ligados aos campos da História e das Letras. $^{28}$ Em 2012, o grupo NEVE promoveu duas importantes atividades na área: a organização do primeiro evento dedicado exclusivamente ao estudo da

\footnotetext{
${ }^{27}$ O capítulo "Vikings", escrito por Johnni Langer, recebeu quatro citações no Google Scholar (acesso em 20 de outubro de 2015).

28 Espelho do grupo NEVE no diretório do CNPQ: dgp.cnpq.br/dgp/espelhogrupo/1520631139904677 Site do grupo: http://neve2012.blogspot.com.br/ O grupo NEVE congrega atualmente três linhas de pesquisa ligadas ao tema: Mitos, ritos, magias: as religiosidades na Escandinávia; Literatura e sagrado na Escandinávia Medieval; Ressignificações da religiosidade medieval no mundo contemporâneo.
}

Horizonte, Belo Horizonte, v. 14, n. 43, p. 909-936, jul./set. 2016 - ISSN 2175-5841 
Escandinávia Medieval e a recriação de um periódico especializado no mesmo tema.

O I Colóquio de Estudos Vikings e Escandinavos, realizado na UFF em outubro de 2012, congregou os investigadores a repensarem seus temas e articulando-se nas possibilidades de avanço e maiores inserções na academia nacional. O boletim Notícias Asgardianas teve o mérito de propagar ainda mais as novas pesquisas, os novos debates e a emergente geração de estudantes e pósgraduandos dedicados exclusivamente ao estudo da fé nórdica. Neste sentido, a edição número 9, com o dossiê Ritos e crenças, levou ao público algumas das mais recentes metodologias de investigação, além das tradicionais, como a análise de fontes literárias e folclóricas, como também os estudos apresentaram temas como mitos celestes e a cultura material da religiosidade, sejam em suas variedades précristãs ou na emergente perspectiva do hibridismo cultural, aplicado ao período de transições religiosas na Escandinávia.

Figura 11

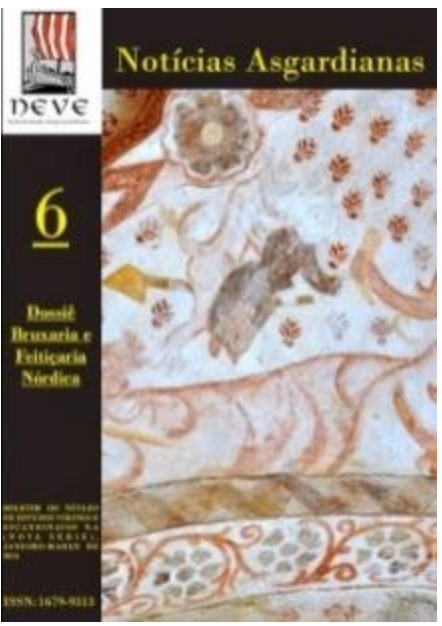

Figura 12

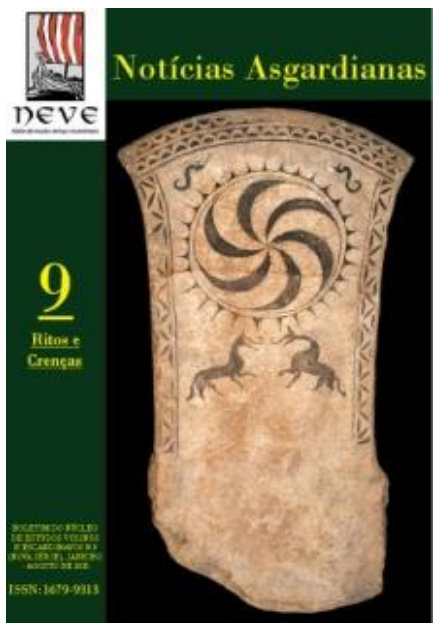

Fontes:

Figura 11: Dossiê: Bruxaria e feitiçaria nórdica, Notícias Asgardianas, n. 6, 2014.

Figura 12: Dossiê: Ritos e crenças, Notícias Asgardianas, n. 9, 2015. 
Figura 13

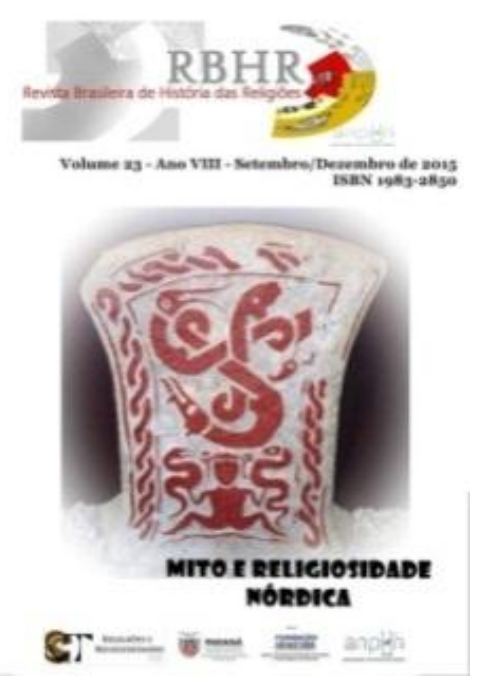

Figura 14

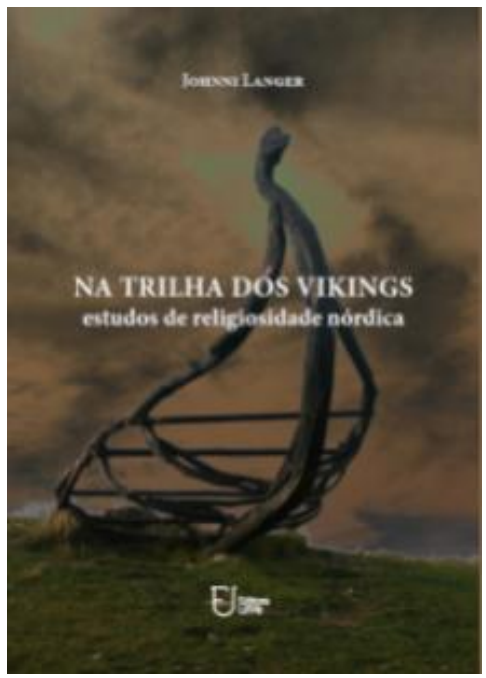

Fontes:

Figura 13: Dossiê: Mito e Religiosidade Nórdica, Revista Brasileira de História das Religiões 23, 2015;

Figura 14: Na trilha dos vikings: estudos de religiosidade nórdica, de Johnni Langer, 2015c. ${ }^{29}$

Outra edição do boletim Notícias Asgardianas (dossiê: Bruxaria e feitiçaria nórdica, edição 6, 2014), também foi um interessante espaço para um assunto muito popular nos nossos dias ${ }^{30}$, mas que ainda carece de muito pouca atenção dos acadêmicos: as crenças envolvendo os praticantes de magia da Escandinávia, cujas representações e discursos foram perpetuados tanto pelo discurso teológico e da Igreja, quanto pelas manifestações artísticas, literárias e folclóricas do final do Medievo. Além de traduções de estudos estrangeiros, o dossiê contou com a participação de pesquisas brasileiras, enfatizando de um lado as concepções clericais (como: Diabolismo e Bruxaria na Escandinávia), quanto, por outro, as manifestações populares sobre o tema (Mandrágora; Gatos e bruxaria nórdica). Percebe-se nitidamente, que a maioria dos estudos deste dossiê estavam preocupados em debater as ideias culturalistas de Carlo Ginzburg sobre um modelo

\footnotetext{
${ }^{29}$ As capas destes periódicos (figuras 11, 12 e 13), reproduzem imagens originais da Antiguidade e Medievo, relacionados diretamente com as crenças e a religiosidade nórdica, demonstrando uma maior maturidade editorial no tratamento visual da temática.

${ }^{30}$ Um sintoma da popularidade do tema é o número expressivo de acessos desta edição do boletim no Academia.Edu: 3.518 visualizações do arquivo (disponível no link: www.academia.edu/6427500, acesso em 08 de novembro de 2015).
} 
de feitiçaria com bases xamanistas euro-asiáticas, ao mesmo tempo em que dialogaram com a obra do mais importante estudioso do tema na Escandinávia, o norte-americano Stephen Mitchell.

Todavia, certamente o momento mais significativo da produção desta época foi a publicação do Dicionário de Mitologia Nórdica: símbolos, mitos e ritos, coordenado pelo grupo NEVE e que contou com a participação de 22 pesquisadores. Além do conteúdo temático, organizado em forma alfabética e contendo mais de 220 verbetes (num total de 581 páginas), a obra possui referências bibliográficas e conteúdos que apontam tanto para uma influência dos clássicos dos estudos nórdicos, como a sua crítica e as mais recentes inovações teóricas e metodológicas. Assim, percebemos Georges Dumézil sendo citado em alguns verbetes (como Balder; Ases e Vanes), mas também é criticado em outros (Tripartição no mundo nórdico); a fenomenologia, o simbolismo e o comparativismo clássico perpassam alguns verbetes (como Mitologia Nórdica), mas são igualmente questionados criticamente no verbete Arquétipos escandinavos. Essa pluralidade teórica apresenta-se de forma positiva aos leitores e pesquisadores iniciantes, porque demonstra tanto a existência de um constante debate, como o direcionar de novos caminhos reflexivos. Outra inovação da obra foi a inclusão de diversas fontes primárias, traduzidas diretamente das diversas linguagens medievais, a exemplo dos poemas éddicos Grímnismál e Rúnatal,31 o Encantamento das Nove Ervas, a Oração de Wessobrunn, A maldição de Busla, o Poema rúnico anglo-saxão, o poema Darraðarljóð e diversas inscrições rúnicas.

Mais recentemente, o grupo NEVE foi convidado a organizar um dossiê para a Revista Brasileira de História das Religiões, o que demonstra o avanço e a inserção desta área no atual panorama das investigações acadêmicas sobre religiões. A edição número 23 (Mito e Religiosidade Nórdica), publicada em outubro de 2015, traz algumas pesquisas de ponta sobre diversos temas em língua portuguesa, totalmente em consonância com a produção internacional.

\footnotetext{
${ }^{31}$ Outra tradução de poesia éddica foi realizada por Elton Medeiros na revista Mirabilia 17, 2013, referente ao poema Hávamál.
} 
Percebemos um maior nível de amadurecimento das pesquisas, mas também detectamos que a área tem ainda inúmeras possibilidades de investigação e é um espaço importante para futuras gerações de pesquisadores do fenômeno religioso. Entre os destaques desta edição, o artigo do historiador Hélio Pires (Vaningi: $O$ javali e a identidade dos Vanir), apresenta um original estudo sobre o simbolismo do javali entre os nórdicos pré-cristãos, ao mesmo tempo em que critica o estruturalismo dumeziliano e as abordagens envolvendo a tripartição na religiosidade germano-escandinava. O estudo constitui uma grande virada nas investigações teóricas sobre a natureza e as funções das divindades no mundo précristão, mas também constitui um excelente modelo de interpretação das fontes primárias e do papel do historiador e do mitólogo.

Outro importante estudo de base teórica e metodológica é Discutindo o Xamanismo no Mito e na Literatura Escandinava: uma breve revisão historiográfica, dos historiadores Maria Emília Monteiro Porto (UFRN) e Pablo Gomes de Miranda (UFRN). Nele, os autores realizam uma sistematização dos debates conceituais sobre o fenômeno do xamanismo, especialmente aplicado para a área escandinava pré-cristã e na literatura medieval. Uma das principais críticas no artigo é sobre a natureza das práticas xamânicas nas fontes primárias e de sua inserção como conceito nas representações modernas.

Por sua vez Luciana de Campos apresenta a pesquisa $A$ sacralidade que vem das taças: o uso de bebidas no Mito e na Literatura Nórdica Medieval, um tema pouco explorado em nosso país: a questão do uso de bebidas em rituais religiosos e sua inclusão nos mitos literários. Outros estudos, como os de André de Oliveira, Munir Ayoub, José Fernandes, Ricardo Menezes, Álvaro Bragança Júnior e 
Andressa Furlan Ferreira, ${ }^{32}$ também realizam excelentes contribuições, tanto com estudos de casos extremamente originais, quanto apontam novos referenciais de análise para o corpus de fontes medievais.

Também recentemente impresso, o novo livro do historiador Johnni Langer, Na trilha dos vikings: estudos de religiosidade nórdica, vem complementar o panorama mais atual de publicações. Trata-se de outra coletânea de artigos, desta vez referente ao período de 2006 a 2010, nos periódicos Signum, RBHR e Brathair. Langer, apesar de dar continuidade aos estudos de mitologia nórdica (O mito do dragão), já apresenta outras inovações, como nos diversos estudos sobre as manifestações mágicas na sociedade escandinava ( $\mathrm{O}$ galdr; $\mathrm{O}$ seidr), ou na investigação do processo de conversão ao cristianismo (Pagãos e cristãos). A maior parte destes estudos utilizou as sagas islandesas, ao mesmo tempo em que também percebemos uma maior influência de autores estrangeiros dedicados à perspectiva culturalista, da literatura oral e da religiosidade nórdica, aqui entendida como um processo extremamente dinâmico e sujeito a constantes variações temporais e geográficas. Entre os autores citados, destacamos Peter Schjødt, John Mckinell, Thomas Dubois e Lars Lönnroth.

A quantidade de trabalhos nacionais produzidos nos últimos três anos é muito grande e não podemos analisá-la historiograficamente no espaço reduzido deste artigo.33 Contudo, vale a pena ressaltar que esta produtividade resulta diretamente do alcance das pesquisas promovidas pela revista Brathair durante

\footnotetext{
${ }^{32}$ A construção da identidade cristã pela Jóns saga helga (Arno Maschmann de Oliveira, André Araújo de Oliveira); Oseberg: rito, mito e memória na construção da identidade nacional norueguesa no século XX (Mário Jorge da Motta Bastos, Munir Lutfe Ayoub); A descoberta do horizonte: a cristianização dos Vikings na América (Gleudson Passos Cardoso, José Lucas Cordeiro Fernandes, André Luiz Campelo dos Santos); O simbolismo da águia na religiosidade nórdica pré-cristã e cristã (Johnni Langer, Ricardo Wagner Menezes de Oliveira, Andressa Furlan Ferreira); As runas de Cristo - aspectos da conversão da Escandinávia Medieval na Idade Média Tardia (Álvaro Alfredo Bragança Júnior).

${ }^{33}$ Mencionamos a título de quantificação de produtividade, as seguintes revistas brasileiras e seus trabalhos envolvendo a religiosidade nórdica medieval após 2012: Relegens Thréskeia, Signum, Roda da Fortuna, Mundo Antigo, Medievalista, Medievalis, Alethéia. Todavia, merece destaque pela expressividade de seus trabalhos o periódico História, Imagem e Narrativas, com os seguintes artigos: Símbolos religiosos dos vikings (edição 12, 2010), de Johnni Langer; Seguindo o urso e o lobo: discussão sobre os elementos religiosos dos berserkir (11, 2010), de Pablo Miranda; Um banquete para Heimdallr $(12,2011)$ de Luciana de Campos; Entre Cristo e Odin (12, 2011); Sobre os anéis de poder (15, 2012), de Pablo Miranda; O zodíaco viking $(16,2013)$, de Johnni Langer; Thor: do mito ao superherói $(18,2014)$, de Leandro Vilar. Também a revista Signum (v. 17, n. 1, 2016) publicou o artigo "O início da missão cristianizadora da Escandinávia e sua interpretação nas Gesta Hammaburgensis de Adam de Bremen", de Lukas Gabriel Grzybowski, concedendo novo olhar ao tema da cristianização dos países nórdicos no medievo.
}

Horizonte, Belo Horizonte, v. 14, n. 43, p. 909-936, jul./set. 2016 - ISSN 2175-5841 
os anos 2000 e de certa maneira, das atividades promovidas pelo grupo NEVE durante o início da década de 2010 (NEVE, 2015). O futuro das pesquisas no Brasil continua sendo muito promissor.

\section{As pesquisas em Programas de Pós-Graduação}

O panorama das pesquisas em cursos regulares de pós-graduação stricto sensu no Brasil, que enfoquem objetivamente a religiosidade nórdica medieval, ainda é muito pequeno. Isso se deve a algumas situações específicas. De um lado, as traduções de fontes medievais para a língua portuguesa ainda são muito escassas. A disponibilidade e o interesse de professores orientadores também é muito reduzida, devido ao fato de existirem poucos especialistas no tema e área. Assim, a maioria das pesquisas concluídas e em andamento são registradas nos programas de pós-graduação em História e muito menos ainda, em programas de Ciências das Religiões e Letras. Isso se deve ao fato de alguns medievalistas cadastrados em programas aceitarem a orientação ou supervisão, mesmo não sendo pesquisadores diretos deste recorte histórico e espacial.

O tema dominante das pesquisas são as religiosidades pré-cristãs: de um lado, os estudos de mitologia nórdica e de outro, os ritos e crenças politeístas. Uma considerável quantidade se dedica ao tema da conversão ou cristianização no medievo e ainda, suas releituras no mundo contemporâneo. Devido ao fato de estar inserida em programas de História, a maioria das pesquisas esteve voltada para o referencial da História Cultural ou culturalista. No campo dos estudos teóricos das religiões, a Fenomenologia ainda predomina, talvez pela tradição brasileira de traduzir clássicos sobre os mitos, como Mircea Eliade. Os estudos teóricos da História das Religiões pelo viés da Escola Italiana ainda são pouco mencionados nas bibliografias analisadas. Outro detalhe perceptível é a quase ausência de estudos sobre a cultura cristã no Medievo nórdico, a exemplo da arte religiosa em igrejas, de temas folclóricos, literários e de religiosidade popular presentes do século XI ao XV. Os escassos trabalhos sobre a Cristandade concentram-

Horizonte, Belo Horizonte, v. 14, n. 43, p. 909-936, jul./set. 2016 - ISSN 2175-5841 
se essencialmente no período de transição entre as religiosidades. E por sua vez, a religiosidade nórdica anterior ao período viking foi deixada de lado, demonstrando uma influência direta das pesquisas internacionais, que também se dedicam muito pouco a este recorte.

\section{Tabela 1 - Áreas das pesquisas}

\begin{tabular}{|c|c|c|c|c|c|}
\hline $\begin{array}{c}\text { Mestrado } \\
\text { defendido }\end{array}$ & $\begin{array}{c}\text { Mestrado } \\
\text { em } \\
\text { andamento }\end{array}$ & $\begin{array}{c}\text { Doutorado } \\
\text { concluído }\end{array}$ & $\begin{array}{c}\text { Doutorado em } \\
\text { andamento }\end{array}$ & $\begin{array}{c}\text { Pós- } \\
\text { Doutorado } \\
\text { concluído }\end{array}$ & $\begin{array}{c}\text { Poutorado } \\
\text { em } \\
\text { andamento }\end{array}$ \\
\hline História (6) ${ }^{34}$ & História (1) 35 & História (3) ${ }^{36}$ & História (1)37 & História (1) $3^{38}$ \\
\hline Letras (1)39 & Letras (1)40 & & \\
\hline $\begin{array}{c}\text { Ciências das } \\
\text { Religiões (1) }\end{array}$ & $\begin{array}{c}\text { Ciências das } \\
\text { Religiões (3) }\end{array}$ & $\begin{array}{c}\text { Ciências das } \\
\text { Religiões (1)43 }\end{array}$ & $\begin{array}{c}\text { Ciências das } \\
\text { Religiões (2)44 }\end{array}$ & & \\
\hline & & Arqueologia (1) 45 & & \\
\hline
\end{tabular}

Fonte: Dados da pesquisa - 2016

\footnotetext{
${ }^{34}$ O guerreiro viking na Edda Poética: religiões, mitos e heróis, de Flávio Palamin (PPGH-UEM, 2013); Godkynningr: o rei escandinavo como ponte entre deuses e homens, de Munir Ayoub (PPGH-PUC-SP, 2013); Guerra e identidade: um estudo da marcialidade na Heimskringla, de Pablo Miranda (PPGH-UFRN, 2013); Rex perpetuus norvegiae: a sacralidade régia na monarquia norueguesa e a santificação de Óláfr Haraldsson, de Renan Birro (PPGH-UFF, 2013); Imaginário e identidade na conversão da Islândia, de André de Oliveira (PPGH-UFMA, 2014); In sorte diaboli: cultura escrita e a construção do imaginário de demonização do pagão na Brennu-nJáls saga (séc. XIII), de José Lucas Cordeiro Fernandes (PPGH-UECE, 2016).

${ }^{35}$ Nas mentes nórdicas: reinterpretando o bastão mágico da völva e desvendando o discurso pagão, de Sara Carvalho Divino (PPGHUEPG).

${ }^{36}$ As representações de honra e vingança nas narrativas mitológicas e heroicas dos Vikings, de Flávio Palamin (PPGH-UEM); A construção da Identidade cristã islandesa na saga do santo Jóns, de André de Oliveira (PPGH-UFMT); Representações de São Miguel arcanjo, de Sigurd Fafnisbáni e a luta contra o mal, de Renan Birro (PPGH-USP).

${ }^{37}$ Orm: o mito do dragão na Escandinávia da Era Viking e cristã, de Johnni Langer (PPGH-USP, 2007).

${ }^{38}$ Cristianismo e legitimação política na Escandinávia Medieval, de Lukas Grzybowski (PPGH-USP).

${ }^{39}$ Die kuniginne rich - o mundo feminino na "canção dos nibelungos" e na "saga dos volsung", de Valéria Sabrina Pereira (PPGL-USP, 2006).

${ }^{40}$ A mulher guerreira na Saga de Hervor: mito e literatura na Escandinávia Medieval, de Luciana de Campos (PPGL-UFPB).

${ }^{41}$ Mito, magia e religião na Volsunga saga: um olhar sobre a trajetória mítica do herói Sigurd, de Suênia de Souza Amorim (PPGCRUFPB, 2013)

${ }^{42}$ Feras petrificadas: o simbolismo religioso dos animais na Era Viking, de Ricardo Menezes (PPGCR-UFPB); Physiologus og fleira: simbolismos religiosos no bestiário medieval islandês, de Andressa Ferreira (PPGCR-UFPB); A concepção apocalíptica na Mitologia Nórdica, de Angela Albuquerque (PPGCR-UFPB). Também registramos um mestrado em História não concluído (desistência), sobre cristianização da Islândia Medieval (PPGH-UFF), de Ana Clara Thomazini Racy, segundo informações do prof. Dr. Mário Jorge Bastos (UFF).

${ }^{43}$ A desconstrução do conceito de saga na Teologia da criação em Karl Barth (PPGCR-UMSP, 2012).

${ }^{44}$ Mito e Rito na Europa Setentrional Pré-Cristã: investigando a Caçada Selvagem na poesia e prosa escandinava do séc. XII - XIV, de Pablo Gomes de Miranda (PPGCR-UFPB); O simbolismo religioso da serpente na Escandinávia da Era Viking (séculos VIII-XI d.C.), de Leandro Vilar Oliveira (PPGCR-UFPB).

${ }^{45}$ Entre ritos e mitos: os ancestrais e a preservação da ordem social através da memória no mundo pré-cristão escandinavo, de Munir Lutfe Ayoub (PPGA-USP).
}

Horizonte, Belo Horizonte, v. 14, n. 43, p. 909-936, jul./set. 2016 - ISSN 2175-5841 


\section{Tabela 2 - Temas das pesquisas}

\begin{tabular}{|c|c|c|c|c|}
\hline $\begin{array}{c}\text { Mitologia } \\
\text { Nórdica }\end{array}$ & $\begin{array}{c}\text { Ritos e } \\
\text { crenças } \\
\text { pré-cristãs }\end{array}$ & $\begin{array}{c}\text { Conversão e } \\
\text { cristianização } \\
\text { da } \\
\text { Escandinávia } \\
\text { Medieval }\end{array}$ & $\begin{array}{c}\text { Cultura cristã } \\
\text { no medievo } \\
\text { nórdico }\end{array}$ & Ressignificações \\
\hline 8 & 7 & 7 & 1 & 1 \\
\hline
\end{tabular}

Fonte: Dados da pesquisa - 2016

Tabela 3 - Referenciais teórico-metodológicos das pesquisas 46

\begin{tabular}{|c|c|c|c|c|c|c|}
\hline Fenomenologia & $\begin{array}{c}\text { Mitologia } \\
\text { Comparada }\end{array}$ & $\begin{array}{c}\text { Imaginário } \\
\text { social }\end{array}$ & $\begin{array}{c}\text { História } \\
\text { Cultural }\end{array}$ & $\begin{array}{c}\text { Arqueologia } \\
\text { das } \\
\text { Religióes }\end{array}$ & $\begin{array}{c}\text { Cultura } \\
\text { visual, } \\
\text { Iconografia }\end{array}$ & $\begin{array}{c}\text { Oralidade, } \\
\text { performance e } \\
\text { dramatização }\end{array}$ \\
\hline 3 & 3 & 2 & 15 & 4 & 4 & 4 \\
\hline
\end{tabular}

Fonte: Dados da pesquisa - 2016

\section{Conclusão}

Os estudos brasileiros sobre religiosidade nórdica já produziram uma razoável quantidade de publicações e eventos, mas ainda são muito pequenos se comparados com outros temas da Medievalística e da História das Religiões instaurada no Brasil. A área tem ainda muito a crescer e já vem demonstrando interesse em discutir as suas próprias maneiras de pesquisar, as suas bibliografias e metodologias.47 Com a eminente titulação dos pesquisadores (citados nas tabelas), a tendência é aumentar a quantidade de orientadores em programas de pósgraduação e como consequência, a possibilidade de novos projetos de pesquisas. 48 Também ocorre a necessidade de maior quantidade de publicação de fontes

\footnotetext{
${ }^{46}$ Algumas pesquisas utilizaram ou utilizam mais de um referencial teórico e metodológico.

47 Exemplo dessa tendência são os recentes trabalhos: O comparativismo nos estudos de Mitologia Nórdica: uma revisão historiográfica, I Semana Acadêmica de Ciências das Religiões, UFPB, 2015; Arqueologia da religião nórdica na Era Viking: perspectivas teóricas e metodológicas, inserido no dossiê: Novas paisagens teóricas e metodológicas nos Estudos Medievais contemporâneos (Signum 16, 2015); Constelações e mitos celestes na Era Viking: reflexões historiográficas e etnoastronômicas (Roda da Fortuna 4, 2015); O comparativismo na História das Religiões Nórdicas, II Simpósio Internacional da ABHR, UFSC, 2016.

${ }^{48}$ Os estudos nórdicos medievais estão ausentes da maioria dos currículos dos cursos de graduação e pós-graduação em História, Letras, Ciências das Religiões e Ciências Humanas em geral no Brasil. Uma exceção é o Programa de Pós-Graduação em Ciências das Religiões da UFPB, o qual vem desde 2014 ofertando disciplinas específicas da área, como A Religião Nórdica Pré-Cristã; Mitologia Escandinava; Arqueologia da religião nórdica antiga.
}

Horizonte, Belo Horizonte, v. 14, n. 43, p. 909-936, jul./set. 2016 - ISSN 2175-5841 
primárias e bibliografias internacionais, bem como uma maior especialização dos pesquisadores brasileiros nos estudos linguísticos medievais.

A Escandinavística é amplamente internacionalizada nos grandes centros de pesquisa do mundo, mas no Brasil ainda caminhamos a passos pequenos. 49 Muitos membros do Núcleo de Estudos Vikings e Escandinavos e outros pesquisadores mantém contato direto com diversos escandinavistas norte-americanos e europeus há muitos anos. Alguns fazem parte de grupos estrangeiros, como Pablo Gomes de Miranda (integrante do grupo Valland da França). Também ocorrem colaboradores estrangeiros do grupo NEVE, registrados no diretório do CNPQ, como Neil Price, Terry Gunnnell e Teodoro Antón. Muitos trabalhos produzidos no Brasil já receberam diversas citações internacionais, o mais conhecido é o artigo "The origins of the imaginary viking"50, de Johnni Langer (publicado na revista Viking Heritage em 2002) e que recebeu cinco citações em livros e seis em artigos em língua inglesa e francesa. Mais recentemente, uma tese de doutorado na Noruega citou um artigo em português de autoria brasileira (LESLIE, 2013). A produtividade brasileira já recebe atenção de pesquisadores europeus e a tendência é que isso aumente ainda mais. O panorama futuro é que alguns brasileiros participem de estágios na Europa e que colaborem diretamente com pesquisas em andamento ou tenham inserção maior em grupos estrangeiros.

Agradecimentos: aos professores Doutor João Lupi (UFSC) e Mestre Pablo Miranda (UFRN) pelas valiosas sugestões ao presente texto. Todas as opiniões são de nossa responsabilidade.

\footnotetext{
${ }^{49}$ Destacamos outro grupo de estudos nórdicos, além do NEVE: o recém criado Leituras da Escandinávia Medieval, que em 2015 organizou um evento na USP (/ Simpósio de Estudos sobre Escandinávia Medieval, contando com duas palestras na área: As cruzadas do norte e a Cristianização imperfeita do Báltico, de André Muceniecks e Considerações sobre a Cristianização da Escandinávia, de Lucas Gabriel Grzybowski). O mesmo grupo também organizou o dossiê Leituras da Escandinávia Medieval na revista Signum (volume 16, n. 3, 2015). Outro grupo voltado aos estudos nórdicos, o NEIBRAM (Núcleo de Estudos Interdisciplinares das Ilhas Britânicas: Antiguidade \& Medievo), foi recentemente encerrado, assim como o Grupo de Estudos Vikings da PUC-SP e o Valknut (Grupo de Estudos Vikings da UFC).

${ }^{50} \mathrm{O}$ artigo recebeu vinte e oito citações no Google Scholar (acesso em 20 de outubro de 2015).
} 


\section{REFERÊNCIAS}

AGDOLIN, Adone. História das religiões: perspectiva histórico-comparativa. São Paulo: Paulinas, 2013.

ALBUQUERQUE, Eduardo Basto de. Da História religiosa à História cultural do sagrado. Ciências da Religião - História e Sociedade, São Paulo, v. 5, n. 5, 2007, p. 34-49.

ALMEIDA, Sérgio Rubens Barbosa de. Manifestações do sagrado na épica medieval: um recorte em três textos. Londrina: Editora da UEL, 2000.

AMORIM, Suênia de Souza. Mito, magia e religião na Volsunga saga: um olhar sobre a trajetória mítica do herói Sigurd. João Pessoa, Dissertação de Mestrado em Ciências das Religiões pela UFPB, 2013.

ANDRÉN, Anders; JENNBERT, Kristina; RAUDVERE, Catharina. Old Norse religion: some problems and prospects. In: ANDRÉN; JENNBERT; RAUDVERE (Eds.). Old Norse Religion in long-term perspectives: origins, changes, and interactions. Lund: Nordic Academic Press, 2006, p. 11-15.

AYOUB, Munir Lutfe. Repensando o conceito de período Viking. Anais do XXI Encontro Estadual de História, ANPUH-SP, 2012, p. 1-14.

BOULHOSA, Patricia Pires. A mitologia escandinava de Georges Dumézil: um reflexão sobre método e improbabilidade. Brathair, Rio de Janeiro, v.6, n. 2, 2006, p. 1-54.

BOULHOSA, Patricia Pires. Breves observações sobre a Edda em Prosa. Brathair, Rio de Janeiro, v. 4, n. 1, 2004, p. 13-18.

CAMPOS, Luciana de (Org.). A religiosidade dos celtas e germanos. São Luís: Editora da UFMA, 2010.

CÂNDIDO, Maria Regina (Org.). Mitologia germano-escandinava: do chaos ao apocalipse. Rio de Janeiro: NEA/UERJ, 2008.

CARDOSO, Ciro Flamarion. A interpenetração da cosmogonia religiosa com a história entre os escandinavos. Nearco, Rio de Janeiro, v. 5, n. 1, 2012.

CARDOSO, Ciro Flamarion. Aspectos da cosmogonia e cosmografia escandinavas.

Brathair, Rio de Janeiro, v. 6, n. 2, 2006, p. 32-48.

CARDOSO, Ciro Flamarion. O paganismo anglo-saxão: uma síntese crítica. Brathair, Rio de Janeiro, v. 4, n. 1, 2004.

CARDOSO, Ciro Flamarion. Beowulf e as estruturas da Escandinávia Pré-Vikings. Notícias Asgardianas, Paraíba, n. 44, 2004. 
CARDOSO, Ciro Flamarion. O paganismo na Europa Setentrional, Brathair, Rio de Janeiro, v. 4, n. 2, 2004.

CAZNÓK, Yara \& NETO, Alfredo. Ouvir Wagner: ecos nietzschianos. São Paulo: Musa, 2000.

DUMÉZIl, Georges. Do mito ao romance. São Paulo: Martins Fontes, 1992.

FUNARI, Pedro Paulo (Org.). As religiões que o mundo esqueceu. São Paulo: Contexto, 2009.

HOLTEN, Birgitte \& GUIMARÃES, Maria Lucia. Desfazendo as ilusões: o dr. Lund e a suposta presença escandinava na terra de Santa Cruz. Locus, Juiz de Fora, v. 3, n. 1, 1997, p. 32-44.

LANGER, Johnni. A Religião Nórdica Antiga: conceitos e métodos de pesquisa. Rever, São Paulo, v. 16, n. 2, 2016, p. 118-143.

LANGER, Johnni. A Arqueologia da Religião Nórdica na Era Viking: perspectivas teóricas e metodológicas. Signum, Belo Horizonte, v. 16, n. 1, 2015a, p. 4-27.

LANGER, Johnni (Org.). Dicionário de Mitologia Nórdica: símbolos, mitos e ritos. São Paulo: Hedra, 2015b.

LANGER, Johnni. Na trilha dos vikings: estudos de religiosidade nórdica. João Pessoa: Editora da UFPB, 2015c.

LANGER, Johnni. Deuses, monstros, heróis: ensaios de mitologia e religião viking. Brasília: Editora da UNB, 2009.

LESLIE, Helen. The Prose Contexts of Eddic Poetry: Primarily in the

Fornaldarsogur. Tese de Doutorado em Estudos Nórdicos, Universidade de Bergen, Noruega, 2013.

LESLIE, Helen. Younger icelandic manuscripts and Old Norse Studies. In: RMN

Newsletter, Helsinki, n. 4, 2012, p. 160-161.

MATTOS, Sonia Heinrich de. Deuses e heróis na Edda Poética e na tetralogia de Wagner. Boletim de Língua e Literatura Alemã, São Paulo, v. 2, n. 240, 1959, p. 1-105.

MIRANDA, Pablo Gomes de. Discussões etimológicas e religiosas sobre os berserkir e os ulfhednar. In: CAMPOS, Luciana de (Org.). A Religiosidade dos Celtas e Germanos. São Luís: Editora da UFMA, 2010, p. 165-175.

MOOSBURGER, Théo de Borba. Prefácio, notas e tradução. Saga dos Volsungos. São Paulo: Hedra, 2009.

NÚCLEO DE ESTUDOS VIKINGS E ESCANDINAVOS. Dossiê: Bruxaria e feitiçaria nórdica. Notícias Asgardianas, Paraíba, n. 6, 2014. 
NÚCLEO DE ESTUDOS VIKINGS E ESCANDINAVOS. Dossiê: Ritos e crenças, Notícias Asgardianas, Paraíba, n.9, 2015.

NÚCLEO DE ESTUDOS VIKINGS E ESCANDINAVOS. Dossiê: Mito e Religiosidade Nórdica, Revista Brasileira de História das Religiões, Paraná, n. 23, 2015.

NUNES, Elton de Oliveira. Teoria e metodologia em história das religiões no Brasil: o estado da arte. História, Questões e Debates, Curitiba, n. 55, jul./dez. 2011, p. 43-58.

OLIVEIRA, João Bitencourt de. Aventura e magia no mundo das sagas islandesas.

Brathair, Rio de Janeiro, v. 9, n. 1, 2009.

PAGE, Raymond Ian. Mitos nórdicos. São Paulo: Centauro, 1999.

PETERS, José Leandro. A História das Religiões no contexto da História Cultural. Faces de Clio, Juiz de Fora, v. 1, n. 1, 2015, p. 87-104.

RODRIGUES, J. Barboza. Exploração do rio Yamundá. Rio de Janeiro: Typographia $\mathrm{N}, 1875$.

RUST, Leandro \& BASTOS, Mario Jorge. Translatio Studii: A História Medieval no Brasil. Signum, Belo Horizonte, v. 10, 2009, p. 163-188.

SCHJØDT, Jens Peter. Reflections on aims and methods in the study of Old Norse Religion. In: RAUDVERE, Catharina \& SCHJØDT, Jens Peter (Eds.). More than mythology: narratives, ritual practices and regional distribution in Pre-Christian Scandinavian religions. Lund: Nordic Academic Press, 2012, p. 263-287.

STURLUSON, Snorri. Edda em Prosa. Tradução de Marcelo Magalhães Lima. Rio de Janeiro: Numen, 1993. 